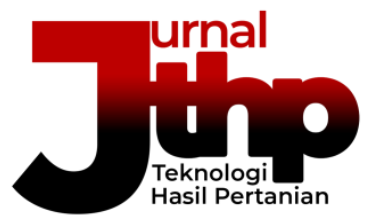

Jurnal Teknologi Hasil Pertanian. 14(1), 62-74 URL: https://jurnal.uns.ac.id/ilmupangan/article/view/47654 DOi: https://doi.org/10.20961/jthp.v14i1.47654

ISSN 1979-0309 (Online) 2614-7920 (Print)

\title{
PENGARUH MIKROORGANISME, BAHAN BAKU, DAN WAKTU INKUBASI PADA KARAKTER NATA: REVIEW
}

\section{THE EFFECT OF MICROORGANISM, RAW MATERIALS, AND INCUBATION TIME ON THE CHARACTERISTIC OF NATA: A REVIEW}

\author{
Sherly Novia Yuana Putri, Wahyu Fajri Syaharani, Cindy Virgiani Budi Utami, \\ Dyah Retno Safitri, Zahra Nur Arum, Zulfa Shafira Prihastari, Anjar Ruspita Sari \\ Program Studi Diploma III Agroindustri, Departemen Teknologi Hayati dan Veteriner, Sekolah Vokasi, \\ Universitas Gadjah Mada, Yogyakarta \\ Email: sherly.novia@mail.ugm.ac.id
}

Diserahkan [6 Oktober 2020]; Diterima [14 Februari 2021]; Dipublikasi [17 Februari 2021]

\begin{abstract}
Nata is an organic food product that has a high fiber content. Nata is a fermented produce by Acetobacter xylinum. There is very limited review article that discussed the making process of nata using different starter, raw material, and the length of incubation time in once. So that, this review discusses the comparison of various parameters that affect the fermentation process of nata. This review aims to discuss the effect of using several types of microorganisms, different raw materials, and different fermentation time on nata production. Factors that influence the success of nata fermentation process include fermentation time, the addition of ingredients (sugar, vinegar, and urea), the use of hollow caps, avoiding products from shocks, and the use of sterile equipment. The bacteria that can be used for making nata include Acetobacter xylinum and Acetobacter $\underline{\mathrm{sp}}$. Several raw materials can be used to make nata, such as coconut water, seaweed, banana peels, tofu water, cassava, and jackfruit straw. The best raw material to make nata from color parameters is seaweed, aroma parameter is jackfruit straw, and taste parameter is cassava. Based on chemical and physical tests, the best raw material for moisture content parameters is seaweed, fiber content parameter is cassava, thickness parameter is banana peel, and yield parameter is coconut water followed by cassava. The length of fermentation affects the thickness and weight of nata, chewier texture of nata, and the darker color of nata. The best thickness of nata produced on the $14^{\text {th }}$ day of fermentation was $1.7 \mathrm{~cm}$. The best overall weight of nata on produced the $10^{\text {th }}$ day of fermentation was $600 \mathrm{~g} / \mathrm{L}$. The texture of nata was the chewiest in the fermentation time of 14 days with the value was $72.33 \mathrm{~g} / 5 \mathrm{~mm}$. The lowest degree of nata whiteness produced on the $14^{\text {th }}$ day of fermentation with the value was $72.307 \%$.
\end{abstract}

Keywords: fermentation; incubation time; nata

\section{ABSTRAK}

Nata adalah salah satu produk makanan organik yang memiliki kandungan serat yang tinggi. Nata merupakan produk hasil fermentasi oleh Acetobacter xylinum. Review yang membahas mengenai pembuatan nata dengan variasi penggunaan starter, bahan baku, dan lama waktu inkubasi secara bersamaan masih sangat terbatas. Sehingga, ulasan ini bertujuan untuk membahas pengaruh penggunaan beberapa jenis mikroorganisme, perbedaan bahan baku, serta lama fermentasi pada proses produksi nata. Faktor yang mempengaruhi keberhasilan proses fermentasi nata meliputi lama fermentasi, penambahan bahan (gula, asam cuka, dan urea), penggunaan tutup berongga, menghindarkan produk dari guncangan, serta penggunaan peralatan steril. Bakteri yang dapat digunakan untuk fermentasi nata di antaranya adalah Acetobacter xylinum dan Acetobacter sp. Bahan baku yang dapat digunakan untuk pembuatan nata di antaranya adalah air kelapa, rumput laut, kulit pisang, air tahu, singkong, dan jerami nangka. Bahan baku nata terbaik dari parameter warna adalah rumput laut, parameter aroma adalah jerami nangka, dan parameter rasa adalah singkong. Berdasarkan uji kimiawi dan fisikawi nata, bahan baku terbaik dari parameter kadar air adalah rumput laut, parameter kadar serat adalah singkong, parameter ketebalan adalah kulit pisang, dan parameter rendemen adalah air kelapa diikuti dengan singkong. Lama fermentasi mempengaruhi ketebalan dan berat nata, kekenyalan nata yang meningkat, dan warna nata makin gelap. Ketebalan nata terbaik dihasilkan pada lama fermentasi hari ke-14 yaitu sebesar 1,7 cm. Berat nata 
terbaik secara keseluruhan dihasilkan pada lama fermentasi hari ke-10 dengan nilai $600 \mathrm{~g} / \mathrm{L}$. Tekstur nata paling kenyal dihasilkan pada lama fermentasi hari ke-14 dengan nilai 72,33 g/5mm. Derajat keputihan nata terendah dihasilkan pada fermentasi hari ke-14 yaitu sebesar 72,307\%.

Kata kunci: fermentasi; nata; waktu inkubasi

Saran sitasi: Putri, S. N. Y., Syaharani, W. F., Utami, C. V. B., Safitri, D. R., Arum, Z. N., Prihastari, Z. S., Sari, A. R. (2021). Pengaruh Mikroorganisme, Bahan Baku, dan Waktu Inkubasi pada Karakter Nata: Review. Jurnal Teknologi Hasil Pertanian, 14(1), 62-74. https://doi.org/10.20961/jthp.v14i1.47654

\section{PENDAHULUAN}

Indonesia merupakan salah satu negara yang memiliki sumber daya yang melimpah, tak terkecuali dengan sumber daya hayati yang dapat dimanfaatkan sebagai sumber pangan yang salah satunya adalah kelapa (Cocus nucifera). Berdasarkan Kurniasih (2020), kelapa merupakan pohon serba guna karena hampir semua bagiannya dapat dimanfaatkan. Menurut Yolanda dan Mulyana (2011), produksi air kelapa di Indonesia sangat melimpah, tetapi pemanfaatannya masih kurang terutama untuk air kelapa tua. Air kelapa tua yang terbuang begitu saja dapat menimbulkan bau menyengat karena polusi asam asetat yang terbentuk akibat fermentasi air kelapa. Padahal, di sisi lain air kelapa dapat dimanfaatkan menjadi produk yang memiliki nilai tambah yang bernilai ekonomi dan kaya akan kandungan gizi. Salah satu produk olahan air kelapa adalah nata yang dapat menjadi produk makanan yang digemari masyarakat.

Nata merupakan salah satu produk makanan organik yang memiliki kandungan serat tinggi melalui fermentasi air kelapa oleh Acetobacter xylinum. Nata memiliki kandungan selulosa yang tinggi, tidak mengandung kolesterol, dan rendah lemak sehingga produk nata tergolong dalam dietary fiber. Nata telah diakui dapat mengendalikan berat badan dan melindungi tubuh dari penyakit divertikulosis, kanker usus besar, dan rektum (Mesomya, 2006).

Nata merupakan makanan yang memiliki bentuk gel dengan tekstur yang kenyal, padat, berwarna putih, dan sedikit transparan. Nata biasanya digunakan sebagai makanan pencuci mulut maupun sebagai makanan kaleng yang dicampur dengan buah-buahan segar (Majesty et al., 2015). Proses fermentasi air kelapa menjadi nata dapat memperkaya variasi produk makanan dan dapat menambah nilai gizi air kelapa yang digunakan. Mengingat semakin hari kebutuhan pangan semakin meningkat sehingga perlu adanya pasokan makanan yang terus menerus dan beragam untuk memenuhi kebutuhan hidup masyarakat.

Pengolahan air kelapa juga dilakukan sebagai upaya diversifikasi produk pangan. Air kelapa yang semula dianggap limbah dan dapat menjadi polusi apabila dibuang ke lingkungan dapat dicegah dengan mengolahnya menjadi produk fermentasi berupa nata. Oleh karena itu, produk hasil fermentasi air kelapa berupa nata menjadi hal menarik yang dapat diulas karena produk nata menjadi salah satu pemanfaatan air kelapa serta melihat banyaknya manfaat kesehatan pada produk nata.

Acetobacter xylinum merupakan bakteri yang digunakan dalam produksi nata yang berperan dalam produksi selulosa. Penggunaan bakteri dapat digantikan dengan Acetobacter sp. yang juga berperan dalam mengubah gula menjadi selulosa pada proses fermentasi. Penggunaan starter yang berbeda-beda dilakukan untuk memaksimalkan produksi nata sehingga menghasilkan karakteristik produk nata yang diinginkan.

Pembuatan nata dapat memanfaatkan bermacam-macam bahan baku, seperti sari buah-buahan dan sayuran selama bahan tersebut sesuai dengan media pertumbuhan Acetobacter xylinum. Menurut Sutarminingsih (2004), aktivitas produksi nata dipengaruhi oleh beberapa faktor di antaranya adalah sumber karbon, sumber nitrogen, suhu fermentasi, tingkat keasaman medium, lama fermentasi, dan konsentrasi starter Acetobacter xylinum. Sumber nitrogen dan sumber karbon diperoleh dari bahan baku yang digunakan untuk membuat nata. Selama ini pembuatan nata umumnya bahan 
dasar air kelapa, akan tetapi pembuatan nata juga dapat dilakukan dengan menggunakan bahan-bahan yang mengandung gula seperti rumput laut, air tahu, jerami nangka, singkong, dan kulit pisang. Bahan-bahan ini bersifat mudah membusuk yang masih dapat diawetkan melalui proses fermentasi.

Pemilihan bahan baku didasarkan pada faktor kemudahan untuk mendapatkan bahan baku, ketersediaan bahan baku, sifat fermentasi, dan harga bahan baku. Variasi penggunaan bahan baku dalam pembuatan nata dilakukan untuk memanfaatkan bahan yang belum optimal padahal dapat memiliki nilai tambah, mengatasi bahan baku yang musiman, dan menciptakan variasi produk olahan nata. Perlakuan variasi bahan baku dalam pembuatan nata dapat memberikan varian rasa dan meningkatkan nutrisi. Adanya variasi penggunaan bahan baku dapat membantu menentukan pilihan bahan baku yang tepat sehingga dapat diperoleh kualitas nata yang paling baik, baik dari segi fisikawi, kimiawi, sensori, maupun kandungan gizi.

Identifikasi lama fermentasi nata dilakukan untuk mengetahui lama fermentasi yang tepat untuk menghasilkan produk nata yang berkualitas baik. Menurut Budiyanto (2003), nata yang berkualitas dapat dilihat berdasarkan kandungan bahan gizi (karbohidrat, protein, lemak, abu, air, dan kadar serat), penampakan produk (ketebalan produk dan berat basah), organoleptik (rasa, bau, warna, dan tekstur), serta kemudahan serat untuk dipisahkan. Budiyanto (2003) menyatakan bahwa kandungan bahan gizi dan tingkat organoleptik pada nata dapat berbeda karena $\mathrm{pH}$ fermentasi, konsentrasi suplementasi, tempat fermentasi, jenis bahan baku yang digunakan, jenis dan konsentrasi starter, dan lama fermentasi. Selain itu, masing-masing mikroorganisme yang digunakan dalam pembuatan nata untuk dapat melakukan fermentasi dengan maksimal membutuhkan lama waktu yang berbeda-beda.

Proses inkubasi dilakukan untuk memperlancar proses pertumbuhan mikroorganisme dalam pembentukan selulosa-selulosa padat yang akan menjadi produk akhir nata. Pengendalian jangka waktu dalam proses inkubasi perlu diperhatikan karena apabila inkubasi fermentasi berlangsung terlalu lama maka nata akan memiliki tekstur yang keras. Fermentasi yang terlalu lama juga berpengaruh terhadap rasa yang dihasilkan, sejalan dengan Salelatu dan Rumahlatu (2016) yang menyatakan bahwa waktu fermentasi yang semakin lama maka kandungan air yang mengisi rongga-rongga antar selulosa semakin banyak yang dapat menyebabkan rasa nata yang semakin menurun. Oleh karena itu perlu dilakukan identifikasi lama waktu fermentasi yang tepat untuk proses pembuatan nata sehingga diperoleh nata yang baik.

Ulasan yang membahas mengenai pengaruh variasi mikrobia, perbedaan bahan baku, serta lama inkubasi sekaligus dalam pembuatan nata masih sangat terbatas. Sehingga, tujuan adanya ulasan ini untuk mengetahui faktor-faktor yang mempengaruhi proses fermentasi nata. Ulasan juga dilakukan untuk mengetahui pengaruh penggunaan beberapa jenis mikroorganisme pada proses pembuatan nata, pengaruh penggunaan perbedaan bahan baku, serta mengetahui pengaruh lama fermentasi terhadap produksi nata yang dihasilkan.

\section{PERAN BAHAN BAKU PEMBUATAN NATA}

Fermentasi adalah suatu proses yang bertujuan untuk meningkatkan umur simpan dan nilai gizi suatu produk dengan memanfaatkan mikroorganisme untuk melakukan perombakan senyawa organik suatu bahan. Pada umumnya, nata merupakan produk fermentasi yang memanfaatkan Acetobacter xylinum yang digunakan starter untuk menyintesis air kelapa sebagai bahan baku menjadi matrik selulosa dengan mengambil glukosa dari larutan gula atau gula dalam air kelapa. Fermentasi nata tergolong jenis fermentasi tidak spontan karena menambahkan starter Acetobacter xylinum yang bersifat aerob dan akan tumbuh optimum pada suhu $28^{\circ} \mathrm{C}$ pada pH 3,5 sampai 7,5. Menurut Sihmawati et al. (2014), produksi nata dapat dipengaruhi oleh 
suhu fermentasi, tingkat keasaman medium, sumber karbon, sumber nitrogen, lama fermentasi, dan konsentrasi starter.

Bahan-bahan yang berperan dalam pembuatan nata meliputi air kelapa, gula, urea, asam cuka, dan Acetobacter xylinum. Air kelapa merupakan bahan utama yang digunakan untuk starter dengan penambahan bakteri Acetobacter xylinum. Adanya starter dalam pembuatan nata merupakan persyaratan yang penting karena berperan dalam memperbanyak jumlah koloni Acetobacter xylinum untuk menghasilkan enzim untuk membentuk nata. Penggunaan asam cuka pada proses fermentasi nata berguna untuk mengatur tingkat keasaman produk. Pengaturan tingkat keasamaan atau $\mathrm{pH}$ bertujuan untuk menyesuaikan dengan karakteristik bakteri, apabila tingkat keasamannya sesuai maka bakteri akan tumbuh dengan optimum dan menghasilkan produk nata dengan maksimal.

Penggunaan urea dalam fermentasi nata berperan sebagai sumber nitrogen bagi pertumbuhan bakteri. Urea dalam proses fermentasi nata akan memberikan pengaruh terhadap ketebalan selulosa yang terbentuk, semakin banyak urea yang ditambahkan maka selulosa yang terbentuk dalam layer juga semakin besar. Menurut Hamad dan Kristiono (2013), pemberian urea akan menghasilkan yield yang lebih besar dibandingkan tidak ditambah urea yang berarti Acetobacter xylinum membutuhkan sumber nitrogen untuk biosintesis selulosa. Penggunaan gula pada nata akan mempengaruhi proses fermentasi karena gula merupakan sumber karbon bagi nata dan sebagian gula yang digunakan tersebut akan disintesis menjadi selulosa dan asam. Air kelapa juga mengandung sebagian nutrisi seperti karbon yang dibutuhkan dalam proses pembuatan nata de coco. Menurut Yanti et al. (2017), banyaknya gula yang ada pada media fermentasi akan mempengaruhi produksi nata, hal ini karena semakin banyak gula yang digunakan maka selulosa ekstraseluler yang terbentuk dari pemecahan gula juga semakin banyak.

\section{PERAN TAHAPAN PROSES PEMBUATAN NATA}

Selain faktor dari bahan baku, perlakuan dalam proses pembuatan nata juga memberikan pengaruh pada hasil akhir nata. Faktor pertama ada pada proses inkubasi, inkubasi dilakukan selama 8 hari dengan suhu $26-28^{\circ} \mathrm{C}$ karena merupakan suhu bakteri Acetobacter xylinum dapat tumbuh dengan optimal. Proses inkubasi dilakukan untuk memperlancar proses pertumbuhan mikroorganisme dalam pembentukan selulosa-selulosa padat yang akan menjadi produk akhir nata. Menurut Latumahina et al. (2017), semakin lama fermentasi maka nata yang terbentuk akan semakin tebal, namun waktu fermentasi yang terlalu lama juga akan membuat warna nata menjadi lebih kecokelatan karena jalinan selulosa yang terbentuk semakin banyak dan tekstur nata menjadi lebih keras.

Penggunaan wadah dan penutup yang berongga bertujuan agar tetap ada oksigen selama proses fermentasi, pemberian perlakuan juga disesuaikan dengan karakteristik bakteri Acetobacter xylinum yang bersifat aerobik atau membutuhkan oksigen dalam pertumbuhannya. Menyimpan produk dan menghindarkan produk dari gerakan atau guncangan yang bertujuan untuk mempertahankan bentuk dan ketebalan nata sehingga dapat dihasilkan produk dengan bentuk dan ketebalan yang sesuai dengan standar yang diinginkan. Sesuai dengan pernyataan Alwi et al. (2011), selama fermentasi berlangsung nata tidak boleh digerakkan atau digoyangkan karena guncangan dapat menyebabkan pecahnya struktur lapisan nata yang terbentuk sehingga didapatkan lapisan nata yang tipis dan terpisah satu sama lainya. Peralatan yang tidak steril dapat menjadi kontaminan pada produk, apabila produk terkontaminasi mikroorganisme lain pertumbuhan Acetobacter xylinum dapat terhambat atau terganggu. 


\section{PENGARUH SPESIES MIKROORGANISME TERHADAP PROSES FERMENTASI}

Proses fermentasi pembuatan nata de coco umumnya melibatkan peran mikroorganisme Acetobacter xylinum. Namun, penggunaan Acetobacter xylinum dapat digantikan dengan alternatif mikroorganisme lain seperti Acetobacter sp. Kedua mikroorganisme tersebut memiliki genus yang sama yaitu Acetobacter, yang membedakan hanya spesiesnya. Kedua mikroorganisme tersebut merupakan bakteri gram negatif, bersifat aerob, dan dapat mensintesis selulosa secara ekstraseluler. Menurut Melliawati dan Djohan (2013), Acetobacter sp. merupakan bakteri lokal yang mempunyai potensi untuk dikembangkan dan digunakan sebagai inokulum yang mampu menghasilkan serat selulosa yang relatif banyak. Mekanisme fermentasi pada Acetobacter xylinum dan Acetobacter sp. secara umum sama karena berasal dari genus yang sama.

Pada proses fermentasi Acetobacter xylinum, terbentuk jaringan mikrofibril selulosa secara ekstraseluler dari heksosa, maltosa dan sukrosa, sedangkan bakterinya terperangkap dalam jaringan mikrofibril. Pembentukan selulosa pada proses fermentasi dimulai dengan munculnya benang-benang pendek yang tersebar seperti lendir yang menutup sel bakteri. Benangbenang tersebut akan terpilin yang lama kelamaan akan berubah berbentuk tali. Benang-benang tersebut akan tersusun menjadi anyaman selulosa yang dikenal sebagai nata.

Pada proses fermentasi Acetobacter sp., karbohidrat pada medium dipecah menjadi glukosa yang kemudian berikatan dengan asam lemak membentuk prekursor selulosa oleh enzim selulosa sintetase kemudian disekresikan membentuk jalinan selulosa pada permukaan medium. Selama proses metabolisme karbohidrat, terjadi proses glikolisis yang dimulai dengan perubahan glukosa menjadi glukosa 6-phospat yang kemudian hasil akhirnya terbentuk asam piruvat. Glukosa 6-P yang terbentuk dalam proses glikolisis yang selanjutnya digunakan oleh bakteri Acetobacter sp. untuk menghasilkan selulosa. Selulosa yang dihasilkan kemudian saling bersatu membentuk biopolimer selulosa. Bakteri akan terperangkap di antara serat-serat biopolimer selulosa. Perbedaan hasil uji sensoris, fisikawi, dan kimiawi fermentasi nata dengan bahan baku air kelapa (Nata de Coco) dari Acetobacter xylinum dan Acetobacter sp. $\mathrm{N}$ terdapat pada Tabel 1.

Tabel 1 Hasil uji sensoris, fisikawi, dan kimiawi nata de coco menggunakan bakteri Acetobacter xylinum dan Acetobacter sp. N

\begin{tabular}{|c|c|c|c|c|c|c|}
\hline \multirow{2}{*}{ No } & \multirow{2}{*}{ Mikroorganisme } & \multicolumn{5}{|c|}{ Hasil Fermentasi } \\
\hline & & \multirow{2}{*}{$\begin{array}{l}\text { Warna } \\
\text { Putih }\end{array}$} & \multirow{2}{*}{$\begin{array}{c}\text { Kenampakan } \\
\begin{array}{c}\text { Licin dan } \\
\text { halus }\end{array}\end{array}$} & \multirow{2}{*}{$\begin{array}{c}\mathrm{pH} \\
5,79-6,41\end{array}$} & Kadar Gula & Kepadatan \\
\hline 1 & $\begin{array}{l}\text { Acetobacter } \\
\text { xylinum (kontrol) } \\
\text { (Suripto, 2018) }\end{array}$ & & & & $\begin{array}{l}\text { Berdasarkan SNI, } \\
\text { Acetobacter } \\
\text { xylinum } \\
\text { menghasilkan } \\
\text { konsentrasi gula } \\
\text { minimal 15\% }\end{array}$ & $\begin{array}{l}20 \mathrm{~g} / 100 \\
\mathrm{~g} \text { nata }\end{array}$ \\
\hline 2 & $\begin{array}{l}\text { Acetobacter sp. } \\
\mathrm{N} \text { (Phong et al., } \\
\text { 2017) }\end{array}$ & $\begin{array}{l}\text { Lebih } \\
\text { banyak } \\
\text { warna } \\
\text { putih }\end{array}$ & $\begin{array}{l}\text { Halus } \\
\text { dengan } \\
\text { kepadatan } \\
\text { yang tinggi }\end{array}$ & $4,0-6,0$ & $\begin{array}{l}\text { Pada artikel } \\
\text { Acetobacter sp. } \\
\text { tidak melakukan } \\
\text { pengujian brix } \\
\text { setelah inkubasi, } \\
\text { namun } \\
\text { penambahan kadar } \\
\text { gula awal } 5^{\circ} \text { Brix } \\
\text { mampu } \\
\text { menghasilkan nata } \\
\text { yang terbaik }\end{array}$ & $\begin{array}{l}71,29 \\
\mathrm{~g} / 100 \\
\text { nata }\end{array}$ \\
\hline
\end{tabular}


Pada uji sensoris warna nata, hasil nata de coco dari bakteri Acetobacter xylinum berwarna putih yang disebabkan warna dari hasil selulosa dan jalinan selulosa hasil perombakan gula. Bakteri Acetobacter sp. N juga menghasilkan nata de coco banyak warna putih karena menggunakan perbandingan gula yang pas yakni $5^{\circ}$ Brix. Kenampakan dari nata de coco dengan fermentasi bakteri Acetobacter xylinum yakni licin dan halus yang disebabkan karena bakteri dapat secara sempurna melakukan pembentukan selulosa sehingga permukaan tampak licin dan halus. Kenampakan nata de coco dengan fermentasi bakteri Acetobacter sp. N menghasilkan permukaan yang halus dan kepadatan yang tinggi. Hal tersebut karena Acetobacter sp. N memiliki kecepatan kepadatan yang tinggi sehingga mampu membatasi kontaminasi mikroorganisme lain dan memproduksi selulosa secara efektif.

Selain sifat sensoris, hasil fermentasi nata de coco dari bakteri Acetobacter xylinum dan Acetobacter sp. juga dapat dianalisis terkait sifat fisikawi dan kimiawinya. Hasil fermentasi dari sifat fisikawi dan kimiawi yang terdiri dari tingkat $\mathrm{pH}$, kadar gula, dan kepadatan. Produk nata dari bakteri Acetobacter xylinum menunjukkan tingkat $\mathrm{pH}$ sekitar 5,79-6,41 sedangkan pada nata dari bakteri Acetobacter sp. menunjukkan penurunan $\mathrm{pH}$ sekitar 4.06,0. Menurut Suharjono et al (2011), penurunan $\mathrm{pH}$ terjadi disebabkan oleh koloni mikroorganisme memproduksi asam asetat, asam glukonat, dan asam laktat. Selain itu, terjadi akumulasi asam glukonat dan konsentrasi gula menurun. $\mathrm{pH}$ nata dari kedua bakteri tidak memiliki perbedaan yang begitu signifikan karena kedua bakteri memiliki genus yang sama sehingga karakteristik dan kemampuan bakteri tidak jauh berbeda.

Produk nata dari bakteri Acetobacter xylinum berdasarkan SNI menunjukkan kebutuhan atau penggunaan kadar gula minimalnya adalah $15 \%$. Minimal penggunaan tersebut dipengaruhi oleh adanya penurunan gula selama proses fermentasi karena gula akan disintesis menjadi asam asetat maka konsentrasi gula akan menurun. Produk nata dari bakteri
Acetobacter sp. tidak dilakukan pengujian brix setelah inkubasi, namun hasil fermentasi akibat penambahan kadar gula awal $5^{\circ}$ Brix mampu menghasilkan nata terbaik. Penambahan kadar gula awal untuk menghasilkan nata terbaik dipilih dengan kadar gula paling sedikit karena kadar gula yang terlalu banyak di awal proses fermentasi akan mengakibatkan terjadinya penumpukan asam glukonat yang dapat menyebabkan warna nata menjadi kekuningan. Kadar gula yang terlalu tinggi dalam media fermentasi dapat memperlambat metabolisme bakteri Acetobacter, lambatnya proses metabolisme terjadi karena pertumbuhan mikroorganisme dipengaruhi oleh kepekatan konsentrasi zat terlarut pada larutan (Lusi et al., 2017).

Selain itu, sifat fisikawi dan kimiawi lainnya yang dapat dibandingkan yakni hasil kepadatan dari nata. Kepadatan nata yang dihasilkan oleh fermentasi Acetobacter xylinum adalah $20 \mathrm{~g} / 100 \mathrm{~g}$ nata. Sedangkan kepadatan nata yang dihasilkan oleh fermentasi Acetobacter sp. adalah 71,29 g/100 g. Padatnya nata yang dihasilkan setelah proses fermentasi dikarenakan kedua bakteri sama-sama menghasilkan enzim yang mampu merombak glukosa menjadi selulosa berupa benang-benang polisakarida. Benangbenang polisakarida akan membentuk matrik/jalinan yang menebal dan memadat dan disebut nata.

\section{PENGARUH BAHAN BAKU TERHADAP PROSES FERMENTASI}

Salah satu faktor yang dapat mempengaruhi proses fermentasi yaitu bahan baku yang digunakan. Bahan baku yang mengandung senyawa organik terutama glukosa dan pati dapat digunakan sebagai substrat dalam proses fermentasi. Umumnya, nata dibuat dengan menggunakan bahan baku air kelapa atau yang biasa disebut dengan nata de coco. Namun, pembuatan nata dapat dilakukan dengan menggunakan berbagai macam bahan baku lainnya, seperti kulit pisang, rumput laut, air tahu, singkong, dan jerami nangka. Bahan baku tersebut samasama mampu menghasilkan nata dengan bantuan bakteri Acetobacter xylinum, tetapi 
nata yang dihasilkan berbeda-beda. Karbohidrat merupakan kandungan pada bahan baku yang mempengaruhi hasil nata selama proses fermentasi, karena karbohidrat digunakan sebagai sumber energi Acetobacter xylinum dalam memproduksi selulosa. Tabel 2 menunjukkan kandungan karbohidrat yang dimiliki oleh bahan baku air kelapa, rumput laut, kulit pisang, air tahu, singkong, dan jerami nangka yang digunakan dalam pembuatan nata.

Tabel 2 Kandungan karbohidrat bahan baku yang digunakan dalam pembuatan nata

\begin{tabular}{ccccccc}
\hline \multirow{2}{*}{ Parameter } & \multicolumn{6}{c}{ Bahan baku } \\
\cline { 2 - 7 } & Air kelapa & $\begin{array}{c}\text { Rumput } \\
\text { laut }\end{array}$ & $\begin{array}{c}\text { Kulit } \\
\text { pisang }\end{array}$ & Air tahu & Singkong & $\begin{array}{c}\text { Jerami } \\
\text { nangka }\end{array}$ \\
\hline Kandungan & $\begin{array}{c}5,23 \% \\
\text { Karbohidrat } \text { (Tih } \text { et } ., \\
2017)\end{array}$ & $\begin{array}{c}33,3 \% \\
(\text { Khotijah } \\
\text { et al., } \\
2020)\end{array}$ & $\begin{array}{c}18,5 \% \\
\text { (Ramadhan } \\
\text { a, 2019) }\end{array}$ & $\begin{array}{c}\text { (Hardianti, } \\
\text { 2019) }\end{array}$ & $\begin{array}{c}\text { (Rahayu, } \\
\text { 2017) }\end{array}$ & $\begin{array}{c}\text { (Hermawani } \\
\text { et } \\
\text { al., 2019) }\end{array}$ \\
\hline
\end{tabular}

Tabel 3 Uji sensoris, fisikawi, dan kimiawi nata menggunakan berbagai macam bahan baku

\begin{tabular}{|c|c|c|c|c|c|c|}
\hline \multirow{2}{*}{ Parameter } & \multicolumn{6}{|c|}{ Bahan Baku } \\
\hline & Air kelapa & $\begin{array}{c}\text { Rumput laut } \\
\text { (Rachmawa } \\
\text { ti et al., } \\
\text { 2017) }\end{array}$ & $\begin{array}{c}\text { Kulit pisang } \\
\text { (Marlinda } \\
\text { dan Hartati, } \\
\text { 2019) }\end{array}$ & $\begin{array}{l}\text { Air tahu } \\
\text { (Tamimi et } \\
\text { al., 2015) }\end{array}$ & $\begin{array}{c}\text { Singkong } \\
\text { (Putriana } \\
\text { dan Aminah, } \\
\text { 2013) }\end{array}$ & $\begin{array}{c}\text { Jerami } \\
\text { nangka } \\
\text { (Rose } e t \\
\text { al., 2018) }\end{array}$ \\
\hline Warna & $\begin{array}{c}\text { Agak } \\
\text { kuning - } \\
\text { putih }\end{array}$ & Transparan & $\begin{array}{c}\text { Putih } \\
\text { kecoklatan }\end{array}$ & $\begin{array}{c}\text { Putih } \\
\text { kekuningan }\end{array}$ & $\begin{array}{l}\text { Putih agak } \\
\text { keruh }\end{array}$ & Coklat \\
\hline Tekstur & $\begin{array}{l}\text { Agak } \\
\text { kenyal }\end{array}$ & Kenyal & Kenyal & $\begin{array}{l}\text { Padat, } \\
\text { kenyal }\end{array}$ & Kenyal & $\begin{array}{l}\text { Kenyal, } \\
\text { tidak keras }\end{array}$ \\
\hline Aroma & $\begin{array}{c}\text { Agak asam } \\
\text { - asam }\end{array}$ & Asam & - & Asam & Tidak asam & $\begin{array}{c}\text { Khas buah } \\
\text { nangka }\end{array}$ \\
\hline Rasa & $\begin{array}{l}\text { Sedikit } \\
\text { asam }\end{array}$ & Tawar & Asam & Asam & Rasa enak & - \\
\hline Kadar air & $\begin{array}{c}97,71 \% \text { - } \\
98,44 \% \\
\text { (Suripto } \text { et } \\
\text { al., 2018) }\end{array}$ & $\begin{array}{c}98,64 \% \\
\text { (starter } \\
7,5 \%)\end{array}$ & $85,8 \%$ & $81,02 \%$ & - & $97 \%$ \\
\hline $\begin{array}{c}\text { Kadar } \\
\text { serat }\end{array}$ & $\begin{array}{c}4,5 \% \\
\text { (starter } \\
10 \%)\end{array}$ & $\begin{array}{c}6,22 \% \\
\text { (starter } \\
15 \%)\end{array}$ & - & $\begin{array}{c}0,64 \% \\
\text { (starter } \\
10 \%)\end{array}$ & $9,43 \%$ & $\begin{array}{c}3,646 \% \\
\text { (starter } \\
10 \%)\end{array}$ \\
\hline Ketebalan & $\begin{array}{c}2,2 \mathrm{~cm} \\
\text { (starter } \\
10 \%)\end{array}$ & $\begin{array}{c}0,41 \mathrm{~cm} \\
\text { (starter } \\
15 \% \text { ) }\end{array}$ & $\begin{array}{c}2,77 \mathrm{~cm} \\
\text { (starter } \\
30 \%)\end{array}$ & - & $\begin{array}{c}1,37 \mathrm{~cm}(14 \\
\text { hari })\end{array}$ & $\begin{array}{c}0,605 \mathrm{~cm} \\
\text { (starter } \\
10 \%)\end{array}$ \\
\hline Rendemen & $\begin{array}{c}90,2 \% \\
\text { (starter } \\
10 \%) \\
\text { (Safitri, } \\
2014 \text { ) }\end{array}$ & $\begin{array}{c}16,15 \mathrm{~g} / \mathrm{L} \\
\text { (starter } \\
15 \%)\end{array}$ & $\begin{array}{c}51,4 \% \\
\text { (starter } \\
30 \%)\end{array}$ & $10,067 \%$ & $59,09 \%$ & - \\
\hline
\end{tabular}

Singkong sebagai bahan baku memiliki kandungan karbohidrat tertinggi yaitu 34,7\%. Hasil menunjukkan bahwa sumber energi pada substrat singkong sangat besar. Nata dari masing-masing bahan baku kemudian diuji secara sensoris, kimiawi, dan fisikawinya. Tabel 3 menunjukkan perbedaan hasil uji sensoris, fisikawi, dan kimiawi masing-masing bahan baku.
Menurut Negara et al. (2016), warna merupakan sensoris pertama yang dapat dilihat langsung oleh konsumen atau panelis. Warna nata dipengaruhi olehjumlah bakteri yang digunakan karena berpengaruh pada ketebalan nata, sedangkan ketebalan nata akan berpengaruh pada warna yang dihasilkan. Semakin tebal nata maka warna akan semakin keruh. Selain itu, warna yang 
dihasilkan pada nata dipengaruhi oleh warna asli bahan baku pembuatan nata. Warna terbaik yaitu pada bahan baku rumput laut dengan warna nata transparan.

Hampir semua tekstur nata dari tiap bahan baku memiliki tingkat kekenyalan yang baik (kenyal). Sesuai dengan pernyataan dari Putriana dan Aminah (2013), tekstur yang baik untuk nata adalah kenyal, padat, dan tidak keras. Nata dengan bahan baku air kelapa merupakan nata yang berperan sebagai produk kontrol, memiliki kekenyalan yang agak kenyal. Sedangkan bahan baku lainnya memiliki tekstur kekenyalan yang kenyal. Oleh karena itu, dapat disimpulkan bahwa nata dengan bahan baku apa saja akan memiliki tekstur kekenyalan yang baik apabila faktor-faktor yang mempengaruhi proses fermentasi tercukupi dengan baik.

Aroma merupakan salah satu faktor penting dalam menentukan mutu suatu bahan pangan karena kesukaan konsumen dipengaruhi oleh aroma dari produk. Hampir semua produk nata dari berbagai bahan baku menghasilkan aroma yang asam, kecuali nata dengan bahan baku singkong dan jerami nangka. Aroma asam yang terdapat pada nata disebabkan aktivitas mikroorganisme selama fermentasi yang menghasilkan produk samping berupa senyawa asam. Bahan baku nata terbaik dari parameter aroma yaitu jerami nangka yang menghasilkan nata yang beraroma khas buah nangka.

Rasa merupakan parameter yang paling berperan dalam penerimaan konsumen terhadap suatu produk. Rasa rasa dipengaruhi oleh beberapa faktor, yaitu senyawa kimia, suhu, konsentrasi, dan interaksi dengan komponen rasa yang lain. Berdasarkan parameter rasa, hampir semua produk nata memiliki rasa yang asam, kecuali pada nata dari bahan singkong yaitu memiliki rasa enak. Rasa asam pada nata disebabkan karena pada proses fermentasi terjadi pengubahan gula menjadi senyawa asam asetat, sehingga $\mathrm{pH}$ akan menurun dan rasa nata menjadi asam.

Kadar air pada produk nata dipengaruhi oleh bahan baku yang digunakan. Selain itu, kadar air dipengaruhi oleh ketebalan nata, semakin tebal nata maka kadar air semakin menurun. Kadar air berkaitan dengan pembentukan selulosa sehingga nata yang tipis memiliki struktur yang lebih rapat dengan kandungan air lebih rendah dan sebaliknya. Menurut Suripto et al. (2018), nata yang bagus memiliki kadar air lebih dari $85 \%$. Berdasarkan hal ini maka kadar air terbaik adalah nata dengan bahan baku rumput laut dengan kadar air 98,64\%.

Kadar serat dipengaruhi oleh kandungan nitrogen dalam medium. Semakin tinggi kadar nitrogen, maka semakin tinggi pula kadar serat nata yang akan terbentuk. Nitrogen digunakan oleh Acetobacter xylinum untuk pembentukan sel-sel baru. Semakin banyak sel yang terbentuk, memungkinkan pembentukan serat nata yang lebih banyak. Kadar serat terbaik yaitu pada nata dengan bahan baku singkong dengan kadar serat sebanyak 9,43\%.

Ketebalan nata diperoleh dari hasil sintesis gula oleh bakteri Acetobacter xylinum yang menghasilkan padatan selulosa. Menurut Effendi dan Utami (2013), ketinggian media dan waktu inkubasi serta interaksi keduanya berpengaruh nyata terhadap ketebalan nata yang terbentuk. Menurut Rose et al. (2018), syarat mutu ketebalan nata menurut SNI berkisar antara 1-1,5 cm. Berdasarkan hasil yang diperoleh, ketebalan bahan yang memenuhi SNI adalah bahan baku air kelapa, kulit pisang, dan singkong. Ketebalan nata terbaik adalah nata dengan bahan baku kulit pisang dengan tebal $2,77 \mathrm{~cm}$.

Rendemen merupakan jumlah produk nata yang dihasilkan dari fermentasi. Rendemen dipengaruhi oleh variasi substrat, komposisi bahan, kondisi lingkungan, dan kemampuan Acetobacter xylinum dalam menghasilkan selulosa. Rendemen terbaik yaitu pada nata dengan bahan baku air kelapa dengan rendemen sebanyak 90,2\%. Sedangkan untuk alternatif lain selain air kelapa rendemen terbaiknya adalah nata bahan baku singkong dengan rendemen sebesar $59,09 \%$. 


\section{PENGARUH LAMA WAKTU INKUBASI TERHADAP PROSES FERMENTASI}

Lamanya waktu inkubasi akan berpengaruh terhadap pembentukan selulosa yang akan semakin tebal dan kokoh, tetapi fermentasi yang terlalu lama akan membuat bakteri Acetobacter xylinum mengalami fase kematian karena kehabisan nutrisi sehingga membuat sel kehilangan banyak energi cadangan. Menurut Putriana dan Aminah (2013), seiring dengan lama fermentasi pertumbuhan akan menurun secara perlahan karena berkurangnya kadar gula dan timbulnya asam sebagai hasil metabolit dari proses fermentasi. Lama waktu inkubasi dalam pembuatan nata yang digunakan terdiri atas 6 hari, 7 hari, 8 hari, 9 hari, 10 hari, 11 hari, 12 hari, 14 hari, 16 hari, dan 21 hari. Parameter yang dibandingkan pada variasi waktu pembuatan nata adalah hasil uji fisikawi meliputi ketebalan, berat nata, dan tingkat kekenyalan. Tabel 4 menunjukkan pengaruh lama inkubasi terhadap parameter fisikawi, kimiawi, dan sensoris masingmasing bahan baku pembuatan nata.

Berdasarkan hasil ketebalan pada Tabel 4. didapatkan nata yang paling tebal ada pada hari ke-14 penelitian Munawwaro (2009) sebesar 1,7 cm. Menurut Lusi et al. (2017), lapisan nata semakin tebal seiring dengan lamanya waktu fermentasi karena bakteri Acetobacter xylinum memanfaatkan nutrisinutrisi yang ada pada substrat secara maksimal sehingga produksi selulosa semakin meningkat. Akan tetapi, penelitian Suzanni et al. (2020) dengan lama waktu 16 hari dan 21 hari menghasilkan ketebalan yang lebih kecil dibanding hari ke-14. Hal tersebut dikarenakan pada penelitian Suzanni menggunakan kadar starter bakteri Acetobacter xylinum hanya 5\%, sedangkan untuk penelitian lainnya setidaknya starter yang ditambahkan adalah $10 \%$.

Nata yang paling berat dihasilkan pada hari ke-10 yaitu sebesar $600 \mathrm{~g} / \mathrm{L}$ (Gresinta et al., 2018). Menurut Maulani et al. (2018), berat nata dipengaruhi oleh ketebalan nata, semakin tebal nata maka akan semakin berat sehingga semakin lama fermentasi maka nata yang dihasilkan akan semakin tebal dan semakin berat. Berdasarkan Tabel 4 tidak dapat dibandingkan antara referensi satu dengan lainnya karena terdapat perbedaan penggunaan starter, wadah fermentasi, banyaknya air kelapa, dan lain-lain. Menurut penelitian Munawwaro (2009), berdasarkan lama fermentasi 8 hari, 11 hari, dan 14 hari menunjukkan semakin lama waktu fermentasi akan menghasilkan nata dengan berat yang semakin meningkat dan berat nata tertinggi ada pada nata fermentasi hari ke-14 yaitu $59,07 \mathrm{~g} / 150 \mathrm{~mL}$.

Menurut Grasinta et al. (2018), berat nata tertinggi terdapat pada nata fermentasi hari ke-10 sebesar 600 g/L. Namun pernyataan bahwa semakin lama fermentasi maka akan dihasilkan nata yang semakin tebal dan berat, tidak sejalan dengan hasil penelitian Asri dan Wisanti (2017), penelitiannya menunjukkan pada fermentasi hari ke-6 nata memiliki berat yang lebih tinggi yakni $231 \mathrm{~g}$ jika dibandingkan pada fermentasi hari ke-9 dan ke-12. Hal ini dapat terjadi karena media sisa ketika fermentasi berjalan di hari ke-6 sudah sangat sedikit dan pada fermentasi hari ke-9 sudah tidak terdapat media sisa sehingga mengakibatkan semakin lama waktu fermentasi nata yang dihasilkan memiliki berat basah yang semakin sedikit. Selain itu, semakin lama fermentasi berlangsung kandungan air dalam substrat akan semakin sedikit karena terjadi penguapan yang mempengaruhi berat basah nata menjadi semakin berkurang.

Tekstur nata de coco yang diinkubasi semakin lama menghasilkan nata yang semakin kenyal. Berdasarkan Tabel 4 didapatkan tekstur nata pada penelitian Munawwaro (2009) menunjukkan kekenyalan tertinggi pada lama fermentasi 14 hari nilainya yaitu $72,33 \mathrm{~g} / 5 \mathrm{~mm}$. Hasil yang diperoleh sesuai dengan pernyataan Munawwaro (2009) yakni perlakuan lama hari fermentasi berpengaruh sangat nyata terhadap kekenyalan nata yang dihasilkan. Semakin lama waktu fermentasi maka bakteri Acetobacter xylinum menghasilkan selulosa yang lebih banyak sehingga kerapatan selulosa akan tinggi dan akan menghasilkan tekstur nata yang lebih kenyal. 
Tabel 4 Uji fisikawi, kimiawi, dan sensoris nata de coco menggunakan lama waktu inkubasi yang berbeda pada pembuatan nata

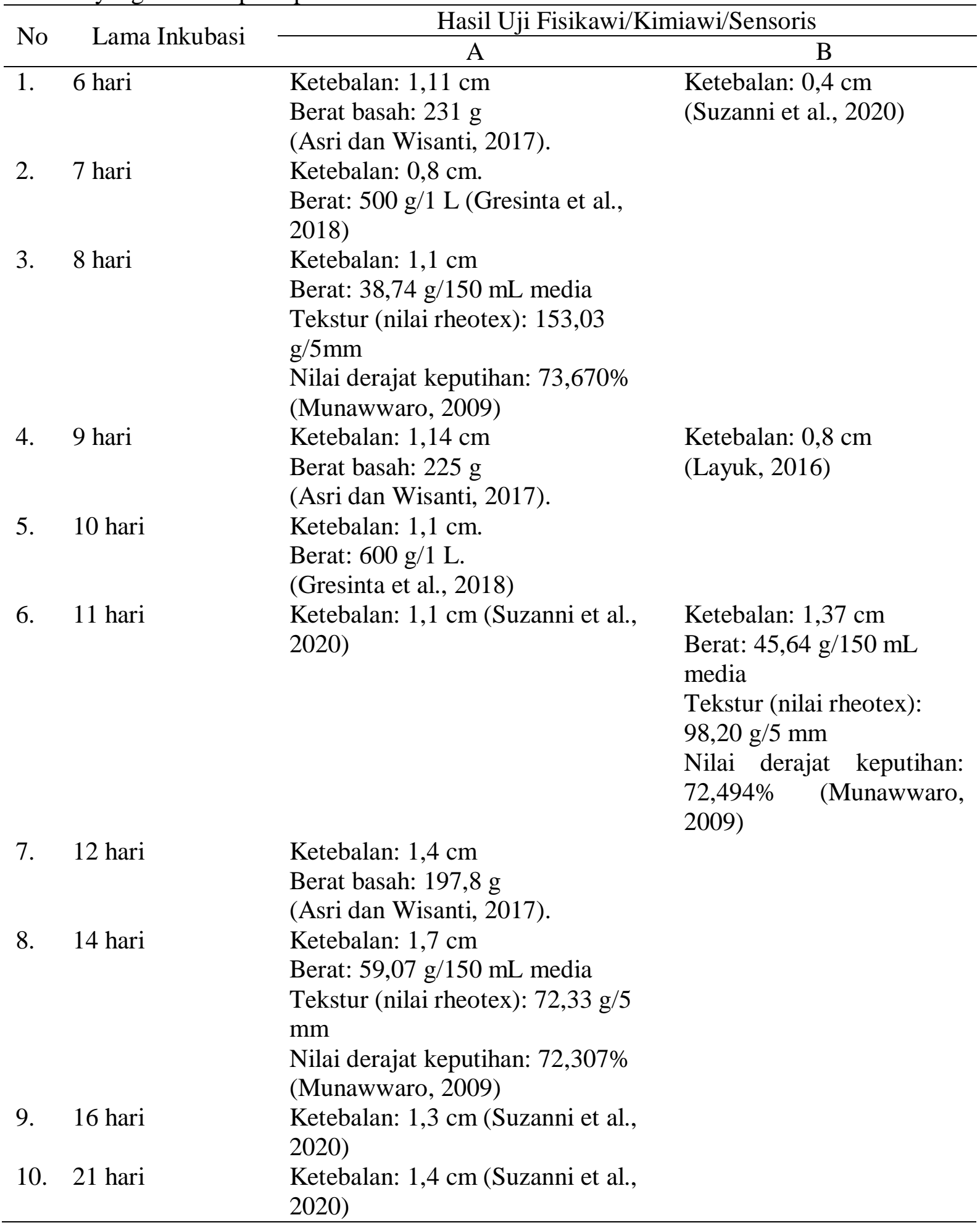

Berdasarkan hasil derajat keputihan pada penelitian Munawwaro (2009) dengan lama fermentasi 8 hari, 11 hari, dan 14 hari yakni derajat keputihan terendah ada pada nata de coco fermentasi hari ke-14 sebesar 72,307\%. Berdasarkan hasil penelitian didapatkan bahwa nilai derajat keputihan dari nata de coco akan semakin rendah seiring dengan lamanya waktu fermentasi. Warna nata berhubungan dengan ketebalan nata, semakin tebal nata maka warna nata akan semakin gelap. Semakin tebal nata maka pembentukan selulosa akan semakin banyak dan memiliki jalinan yang lebih rapat sehingga membuat warna nata semakin gelap. 


\section{KESIMPULAN}

Nata de Coco merupakan salah satu produk fermentasi yang memanfaatkan bakteri Acetobacter xylinum untuk merubah gula dalam air kelapa menjadi selulosa pembentuk nata. Pemilihan produk didasarkan pada pemanfaatan limbah air kelapa yang mampu meningkatkan nilai produk dari segi gizi dan segi penjualan. Faktor yang mempengaruhi proses fermentasi nata meliputi lama fermentasi, penambahan bahan (gula, asam cuka, dan urea), penggunaan tutup berongga, menghindarkan produk dari guncangan, dan penggunaan peralatan steril. Penggunaan mikroorganisme yang berbeda juga mempengaruhi hasil fermentasi secara sensoris, fisikawi, dan kimiawi.

Secara sensoris, mikroorganisme Acetobacter xylinum dan Acetobacter sp. menghasilkan warna nata yang sama yaitu putih. Secara fisikawi dan kimiawi, $\mathrm{pH}$ yang diperoleh Acetobacter sp. lebih rendah daripada Acetobacter xylinum yaitu 4-6. Kepadatan nata yang dihasilkan oleh fermentasi Acetobacter xylinum adalah 20 $\mathrm{g} / 100 \mathrm{~g}$ nata lebih rendah dibandingkan kepadatan nata yang dihasilkan oleh fermentasi Acetobacter sp. adalah 71,29 g/100 g. Penggunaan bahan baku yang berbeda diperoleh hasil bahan baku nata terbaik dari parameter warna adalah rumput laut, parameter aroma adalah jerami nangka, parameter rasa adalah singkong. Berdasarkan uji kimiawi dan fisikawi, bahan baku terbaik dari parameter kadar air adalah rumput laut, parameter kadar serat adalah singkong, parameter ketebalan adalah kulit pisang, dan parameter rendemen adalah air kelapa diikuti dengan singkong. Lama fermentasi dapat meningkatkan ketebalan dan berat nata, tekstur lebih kenyal, dan warna nata makin gelap.

\section{REKOMENDASI}

Berdasarkan review yang telah dilakukan, peluang yang dapat dilakukan untuk kajian lebih lanjut pada pembuatan nata adalah perbandingan variasi jumlah starter pada penggunaan Acetobacter xylinum dan Acetobacter sp. secara bersamaan, pengaruh penambahan bahan tambahan sebagai alternatif sumber nitrogen, serta pengaruh konsentrasi bahan baku dalam pembuatan nata.

\section{DAFTAR PUSTAKA}

Budiyanto, A. K. (2003). Mikrobiologi Terapan. Malang: Universitas Muhammadiyah Malang Press.

Alwi, M., Rahmiati, R., \& Umrah, U. (2011). Pemanfaatan Limbah Cair Tahu (Whey Tahu) Sebagai Media Tumbuh Acetobacter xylinum untuk Memproduksi Nata. Biocelebes 5(2): 91-98.

Asri, M. T. \& Wisanti. (2017). Kualitas Nata de Coco Hasil Fermentasi dengan Jenis Stater dan Lama Inkubasi yang Berbeda. Prosiding Seminar Nasional Hayati V 2017: 76-80.

Effendi, D. S., \& Utami, S. (2013). Pengaruh Penggunaan Bahan Dasar dan Jenis Gula Terhadap Tebal Lapisan dan Uji Organoleptik Nata Sebagai Petunjuk Praktikum Biologi Kd. 2.2 Semester Ganjil Kelas X. Jurnal Pendidikan 19(1): 1-10.

Gresinta, E., Pratiwi, R. D., Damayanti, F., \& Putra, E. P. (2019). Komparasi Yield Nata De Tomato Dengan Nata De Coco Berdasarkan Durasi Fermentasi. IJIS Edu: Indonesian Journal of Integrated Science Education 1(2): 169-174.

Hamad, A. dan Kristiono, K. (2013). Pengaruh Penambahan Nitrogen Terhadap Hasil Fermentasi Nata de Coco. Majalah Ilmiah Momentum 9(1): 62-65.

Hardianti, B. D. (2019). Pengaruh Penambahan Jenis Gula Terhadap Berat dan Tebal Nata de Soya. SainsTech Innovation Journal 2(1): 14.

Hermawani. R. R., Ramadhani, D., Daya, A. M., Wahyudi, F., \& Sukemi. (2019). Nutrisi Tepung Kulit dan Jerami Nangka. Prosiding Seminar Nasional Kimia 2019: 76. 
Khotijah, S., Irfan, M., \& Muchdar, F. (2020). Komposisi Nutrisi Pada Rumput Laut Kappaphycus Alvarezii. Jurnal Agribisnis Perikanan 13(2): 139-146

Kurniasih, Eka. (2020). Merancang Energi Masa Depan dengan Biodiesel. Yogyakarta: Penerbit Andi.

Latumahina, M., Awan, A., \& Rumahlatu, D. (2017). Pengaruh Suhu dan Lama Fermentasi Terhadap Uji Organoleptik pada Pembuatan Nata Buah Enau (Areng pinNata Merr). BIOPENDIX: Jurnal Biologi, Pendidikan dan Terapan 4(1): 29-37.

Layuk, P., Lintang, M., \& Joseph, G. H. (2016). Pengaruh Waktu Fermentasi Air Kelapa Terhadap Produksi dan Kualitas Nata De Coco. Buletin Palma 13(1): 4145.

Lusi, L., Periadnadi, P., \& Nurmiati, N. (2017). Pengaruh Dosis Gula dan Penambahan Ekstrak Teh Hitam Terhadap Fermentasi dan Produksi Nata de Coco. Metamorfosa: Journal of Biological Sciences 4(1): 126-131.

Majesty, J., Argo, B. D., \& Nugroho, W. A. (2015). Pengaruh Penambahan Sukrosa dan Lama Fermentasi Terhadap Kadar Serat Nata dari Sari Nanas (Nata de Pina). Jurnal Leteknikan Pertanian Tropis dan Biosistem 3(1): 80-85.

Marlinda, M., \& Hartati, R. (2019). Optimalisasi Karakteristik Nata de Banana Skin Melalui Perubahan Konsentrasi Acetobacter xylinum. Jurnal Optimalisasi 5(2): 52-59.

Maulani, T. R., Hakiki, D. N., \& Nursuciyoni. (2018). Karakteristik Sifat Fisikokimia Nata De Taro Talas Beneng dengan Perbedaan Konsentrasi Acetobacter xylinum Dan Sumber Karbon. Jurnal Teknologi Industri Pertanian 28(3): 294-299

Melliawati, R., \& Djohan, A. C. (2013). Analisis Karboksimetil Selulosa dari Bakteri Acetobacter xylinum dan Acetobacter sp. RMG-2. Berita Biologi 12(3): 335-344.
Mesomya, W., Pakpeankitvatana, V., KOmindr, S., Leelahakul, P., Cuptapun, Y., Hengsawadi, D., Tammarate, P., \& Tangkanakul, P. (2006). Effect of Health Food from Cereal and Nata de Coco on Serum Lipids in Human. Journal of Nutraceutical and Fumetional Food 28(1): 23-28.

Munawwaro, S. (2009). Pengaruh pH Media dan Lama Fermentasi Terhadap Hasil Nata De Coco (Doctoral dissertation).

Negara, J. K., Sio, A. K., Rifkhan, R., Arifin, M., Oktaviana, A. Y., Wihansah, R. R. S., \& Yusuf, M. (2016). Aspek mikrobiologis, serta Sensori (Rasa, Warna, Tekstur, Aroma) Pada Dua Bentuk Penyajian Keju yang Berbeda. Jurnal Ilmu Produksi dan Teknologi Hasil Peternakan, 4(2): 286-290.

Phong, H. X., Lin, L. T., Thanh, N. N., Long, B. H. D., \& Dung, N. T. P. (2017). Investigating The Conditions for NataDe-Coco Production by Newly Isolated Acetobacter Sp. American Journal of food and Science and Nutrition 4(1): 16.

Putriana, I., Aminah, S. (2013). Mutu fisik, Kadar Serat dan Sifat Organoleptik Nata De Cassava Berdasarkan Lama Fermentasi. Jurnal Pangan dan Gizi 4(1): 29-38.

Rachmawati, N. A., Haryati, S., Munandar, A., Km, J. R. J., \& Pakupatan, S. B. (2017). Karakteristik Nata de Seaweed dengan Konsentrasi Bakteri Acetobacter xylinum. Jurnal Perikanan dan Kelautan 7(2): 112-124.

Rahayu, A. (2017). Pengaruh Lama Pengeringan dan Konsentrasi Asam Laktat Terhadap Tepung Tapioka Termodifikasi (The Effect of Drying Time and Concentration Latic Acid To Modified Tapioka Starch) (Doctoral dissertation, Undip).

Ramadhana, H. (2019). Pemanfaatan Limbah Kulit Pisang Raja (Musa textillia) menjadi Karbon Aktif sebagai Kapasitansi Elektroda Superkapasitor 
(Doctoral dissertation, Universitas Islam Negeri Alauddin Makassar).

Rose, D., Ardiningsih, P., \& Idiawati, N. (2018) Karakteristik Nata de Jackfruit (Artocarpus heterophyllus) dengan Variasi Konsentrasi Starter Acetobacter xylinum. Jurnal Kimia Khatulistiwa 7(4): 1-7.

Safitri, M. A. (2014). Pembuatan Nata De Cassava Dari Singkong (Manihot Utilissima Pohl) Untuk Skala Industri Rumahan.

Salelatu, J., \& Rumahlatu, D. (2016). Pengaruh Lama Fermentasi Terhadap Cita Rasa Nata de Salacca. BIOPENDIX: Jurnal Biologi, Pendidikan Dan Terapan 3(1): 46-52.

Sihmawati, R. R., Oktoviani, D, \& Wardah. (2014). Aspek Mutu Produk Nata De Coco Dengan Penambahan Sari Buah Mangga. HEURISTIC: Jurnal Teknik Industri 11(2): 63-74.

Suharjono, S., Ardyati, T., Zubaidah, E., Munawaroh, M., \& Pradani, C. (2011). Produksi Selulosa Bakterial Dari Air Buah Kelapa Dalam Berbagai Konsentrasi Sukrosa Dan Urea (Production of Bacterial Cellulose From Coconut Fruit Water. In Proceeding Biology Education Conference: Biology, Science, Environmental, and Learning 8(1): 124-128.

Sutarminingsih, L. (2004). Peluang Usaha Nata de Coco. Yogyakarta: Kanisius.
Suripto, U. S. (2018). Identifikasi Mutu Pasca Panen Nata de Coco Berdasarkan Lama Perendaman dan Perebusan. Inovasi Agroindustri 1(1): 29-37.

Suzanni, M. A., Munandar, A., \& Saudah, S. (2020). Pengaruh Konsentrasi Ekstrak Nanas (Ananas comosus) Dan Waktu Fermentasi Pada Pembuatan Nata De Coco Dari Limbah Air Kelapa. Jurnal Serambi Engineering 5(2): 1043-1049.

Tamimi, A. (2015). Pengaruh Penambahan Sukrosa dan Urea Terhadap Karakteristik Nata De Soya Asam Jeruk Nipis-In Press. Jurnal Bioproses Komoditas Tropis, 3(1): 1-10.

Tih, F. T. F., Pramono, H., Hasianna, S. T., Naryanto, E. T., Haryono, A. G., \& Rachman, O. (2017). Efek Konsumsi Air Kelapa (Cocos nucifera) terhadap Ketahanan Berolahraga Selama Latihan Lari pada Laki-laki Dewasa Bukan Atlet. Global Medical \& Health Communication 5(1): 37.

Yanti, N. A., Ahmad, S. W., Tryaswaty, D., \& Nurhana, A. (2017). Pengaruh Penambahan Gula dan Nitrogen pada Produksi Nata de Coco. BioWallacea: Jurnal Penelitian Biologi (Journal of Biological Research) 4(1): 541-546.

Yolanda, H. \& Mulyana, Y. (2011). Uji Coba Penggunaan Limbah Air Kelapa Tua sebagai Bahan Dasar Media Isolasi. Jurnal Majalah Kedokteran Bandung 43(3): 117-121. 